\title{
PENGARUH MODEL PEMBELAJARAN GROUP INVESTIGATION TERHADAP KEMAMPUAN MENULIS ARTIKEL ILMIAH PADA MAHASISWA PENDIDIKAN GEOGRAFI
}

\author{
1) Nila Restu Wardani; ${ }^{2)}$ Yuli Ifana Sari \\ 1) ${ }^{2)}$ Universitas Kanjuruhan Malang \\ Email: ${ }^{1)}$ nilarestu@ unikama.ac.id; ${ }^{2)}$ ifana@unikama.ac.id
}

\begin{abstract}
Abstrak
Model pembelajaran Group Investigation mengarahkan mahasiswa untuk menemukan informasi berdasarkan kenyataan di lapangan. Hasil penemuan mahasiswa dapat dituliskan melalui karya illmiah dalam bentuk artikel ilmiah. Mahasiswa menuliskan laporan hasil investigasi di lapangan berdasarkan kaidah-kaidah penulisan yang logis dan sistematis. Jenis penelitian ini adalah penelitian Quasy Experiment (eksperimen semu). Subjek penelitian yaitu mahasiswa kelas A (kelas eksperimen) dan B (kelas kontrol) Program Studi Pendidikan Geografi FIP Universitas Kanjuruhan Malang semester ganjil 2016/2017. Instrumen yang digunakan yaitu rubrik penilaian untuk mengukur kemampuan menulis artikel ilmiah. Data hasil penilaian artikel ilmiah mahasiswa kemudian dianalisis menggunakan t-test dengan taraf signifikan 5\%. Selanjutnya dilihat rata-rata nilai kemampuan menulis artikel ilmiah yang lebih tinggi untuk mengetahui ada tidaknya pengaruh model Group Investigation. Perolehan data menunjukkan rata-rata nilai kemampuan menulis artikel ilmiah pada kelas eksperimen 83,33 dan kelas kontrol 72,27. Rata-rata nilai kelas eksperimen lebih tinggi daripada kelas kontrol dan hasil analisis $\mathrm{H}_{0}$ menunjukkan nilai sig.2-tailed $=0,000$ atau $<0,05$. Jadi, $\mathrm{H}_{0}$ ditolak dan $\mathrm{H}_{1}$ diterima atau model pembelajaran Group Investigation berpengaruh terhadap kemampuan mahasiswa menulis artikel ilmiah.
\end{abstract}

Kata Kunci: Group Investigation, artikel ilmiah.

\section{PENDAHULUAN}

Group Investigation adalah model pembelajaran yang melibatkan mahasiswa sejak perencanaan, menetukan topik, dan investigasi langsung ke lapangan. Model pembelajaran Group Investigation diidentikkan dengan mahasiswa melakukan investigasi ke lapangan dilanjutkan dengan pembuatan laporan. Model pembelajaran ini menuntut mahasiswa untuk memiliki kemampuan yang baik dalam berkomunikasi, maupun dalam keterampilan proses kelompok (group process skills).

Model pembelajaran Group Investigation berawal dari perspektif filosofis terhadap konsep belajar. Group Investigation merupakan bentuk pembelajaran kooperatif yang berasal dari jamannya John Dewey (1970) dan telah diperbaharui dan diteliti pada beberapa tahun terakhir oleh Sholmo dan Yael Sharan, serta RachelLazarowitz di Israel (Widodo, 2015). Gagasan Dewey akhirnya diwujudkan dalam model pembelajaran Group Investigation yang kemudian dikembangkan oleh Herbert Thelen. Dewey menggagas konsep pendidikan bahwa "kelas seharusnya merupakan cermin masyarakat dan berfungsi sebagai laboratorium untuk belajar tentang kehidupan nyata" (Arends, 2008). Fokus Group Investigation ialah pada pembelajaran bagaimana disiplin akademis membentuk dan membangun pengetahuan dan bagaimana cara mengembangkannya dengan inkuiri (Joice, 1996). 
Berdasarkan gagasan di atas dapat dikatakan bahawa Group Investigation memiliki tiga konsep utama, yaitu: pembelajaran kooperatif yang melibatkan kerjasama dalam kelompok, pembelajaran kontekstual atau berdasarkan kehidupan nyata, penemuan atau inkuiri. Konsep utama ini menjadi dasar enam langkah dalam model pembelajaran Group Investigation. Keenam langkah tersebut yaitu: 1) mengidentifikasi topik dan mengatur ke dalam kelompokkelompok penelitian (grouping); 2) merencanakan investigasi di dalam kelompok (planning); 3) melaksanakan kerja di lapangan (investigation); 4) menyiapkan laporan akhir (organizing); 5) mempresentasikan laporan akhir (presenting), dan 6) evaluasi (evaluating).

Keenam langkah dalam Group Investigation menuntun mahasiswa untuk memecahkan permasalahan setelah itu menganalisis serta mengevaluasi sebuah permasalahan. Melalui langkah tersebut, mahasiswa akan terlibat dan mengetahui langsung permasalah yang ada di lapangan. Dalam Group Investigation, mahasiswa melakukan investigasi langsung di lapangan tentang topik-topik yang dipelajari di dalam kelas. Model pembelajaran ini selain melatih mahasiswa untuk bekerjasama secara kelompok juga melatih belajar secara kontekstual atau dengan situasi dunia nyata yang ada di lapangan.

Kardi (2009) menjelaskan bahwa "pembelajaran dengan melakukan investigasi ke lapangan juga dikenal dengan experiental learning, real world education, active learning, dan learned centered instruction". Asumsi pembelajaran tersebut adalah (a) belajar yang baik adalah jika mahasiswa terlibat secara pribadi dalam pengalaman belajarnya, (b) pengetahuan harus ditemukan mahasiswa sendiri agar mereka memiliki arti dalam berbagai perilaku yang mereka pelajari, (c) mahasiswa harus memiliki komitmen terhadap belajar dalam keadaan paling tinggi dan berusaha secara aktif untuk mencapainya dalam kerangka kerja tertentu.

Suprijono (2009) menyatakan bahwa "pembelajaran dengan investigasi ke lapangan terkait dengan interaksi atau hubungan erat antara mahasiswa dengan pengalaman sesungguhnya". Hal ini berarti bahwa mahasiswa bisa menerapkan ilmu yang diperoleh selama perkuliahan ke dalam dunia nyata yang berhubungan dengan peran dan tanggung jawabnya sebagai anggota keluarga, lingkungan sosial dan budaya masyarakat. Pembelajaran kontekstual menyandarkan pada memori spasial, mengintegrasikan berbagai disiplin ilmu, menghubungkan informasi baru dengan pengetahuan yang telah dimiliki mahasiswa, serta penerapan praktis pemecahan problem nyata.

Peacock (2006) menyatakan bahwa "Group Investigation memperluas wawasan dan merangsang minat baru mahasiswa. Lingkungan luar kelas tidak ada batasan untuk pengalaman dan keingintahuan mahasiswa". Mahasiswa sering menemukan potensi, kemampuan dan minat pada dirinya dan orang lain. Pembelajaran ini dapat memotivasi dan menumbuhkan inspirasi mahasiswa. Belajar di luar ruangan menjadi lebih terintegrasi dengan memperhatikan perkembangan pribadi dan sosial mahasiswa.

Sumarmi (2012) menyatakan bahwa "pembelajaran di luar kelas layak diterapkan pada perkuliahan Geografi 
karena Geografi merupakan salah satu cabang ilmu terapan yang mempunyai kandungan ilmu yang luas berupa interaksi antara kondisi fisik dengan keberadaan manusia". Dalam mengkaji ilmu Geografi, dijumpai adanya objek material dan formal. Dimana objek material menekankan pada gejala-gejala yang terjadi di muka bumi melalui berbagai fenomena geosfer (hidrosfer, atmosfer, pedosfer, biosfer, litosfer, dan antroposfer), sedangkan objek formal merupakan cara pandang terhadap objek material. Pembelajaran Geografi menekankan bagaimana mempelajari fenomena hubungan timbal balik/interaksi antara manusia dengan alam dalam sudut pandang kewilayahan/kelingkungan dalam konteks keruangan.

Dalam Group Investigation, mahasiswa diharapkan mampu mendefinisikan secara bebas dan mengobservasi langsung objek studi geografi yang berupa fenomena geosfer dan permasalahan yang terjadi di dalamnya. Mahasiswa diharapkan aktif belajar dan berdiskusi yang dilakukan dengan jalan observasi terhadap objek empiris atau objek yang sesungguhnya terjadi (faktafakta) di muka bumi. Kegiatan ini memunculkan suatu program pengajaran yang menciptakan lingkungan sebagai peluang berlangsungnya proses belajar efektif.

Kelebihan yang dijelaskan tentang Group Investigation memang memberikan pengaruh positif terhadap pembelajaran, bahkan mampu menjadi terobosan teknik pembelajaran yang menarik saat ini. Sebagai suatu model mengajar yang menjadi pilihan, Group Investigation memiliki beberapa kelebihan yaitu: 1) Melatih mahasiswa untuk mendesain suatu penemuan; 2) Melatih berpikir dan bertindak kreatif;
3) Dapat memecahkan masalah yang dihadapi secara realistis; 4) Mengidentifikasi dan melakukan penyelidikan; 5) Menafsirkan dan mengevaluasi hasil pengamatan; 6) Merangsang perkembangan kemajuan berpikir mahasiswa untuk menghadapi masalah secara tepat.

Namun, Group Investigation juga memiliki kelemahan yaitu membutuhkan waktu yang lama karena berlangsung di luar kelas. Setiap aktivitas yang dilakukan mahasiswa tidak dapat dikontrol secara penuh oleh dosen karena mahasiswa memiliki kebebasan penuh untuk menggali informasi di lapangan. Saat mahasiswa melakukan investigasi ke lapangan diperlukan dasar teori yang memadai agar bersinergi antara ilmu yang diperoleh di dalam dan di luar kelas, serta tidak hanya bermain-main saja. Terkadang disiplin mahasiswa kurang dapat diatasi, sehingga tugas yang sesungguhnya terlupakan. Dalam investigasi ke lapangan dibutuhkan rancangan pembelajaran yang lebih rumit serta pembelajaran lintas topik atau lintas pokok bahasan.

Group Investigation akan membiasakan mahasiswa berpikir serta menganalisis. Group Investigation menuntut mahasiswa untuk menyusun laporan hasil investigasi ke lapangan. Hal ini dilakukan agar mahasiswa memiliki keterampilan dalam menyampaikan hasil perolehan data, analisis, kesimpulan dan mampu mempertanggungjawabkan penemuan ilmiah secara tertulis. Dengan melakukan investigasi langsung ke lapangan, diduga dapat meningkatkan kemampuan mahasiswa menulis artikel ilmiah. Hal ini didukung penelitian yang dilakukan Ayu (2012) bahwa "model pembelajaran Group 
Investigation berpengaruh signifikan terhadap hasil belajar kognitif, hasil belajar afektif, dan keterampilan kerja ilmiah mahasiswa IPA Universitas Wiraraja Sumenep Madura". Mahasiswa IPA yang diperlakukan dengan model pembelajaran Group Investigation menunjukkan peningkatan hasil belajar kognitif sebesar 29\% dibandingkan kelas kontrol, hasil belajar afektif menunjukkan peningkatan $24 \%$ dibandingkan kelas kontrol, dan keterampilan menulis karya ilmiah sebesar $60 \%$ dibandingkan kelas kontrol.

Model pembelajaran Group Investigation mengarahkan mahasiswa untuk menemukan informasi berdasarkan kenyataan di lapangan. Hasil penemuan mahasiswa dapat dituliskan melalui karya illmiah dalam bentuk artikel ilmiah. Mahasiswa menuliskan laporan hasil investigasi di lapangan berdasarkan kaidah-kaidah penulisan yang logis dan sistematis. Selanjutnya, mahasiswa mampu menyampaikan mempertanggungjawabkan artikel ilmiah tersebut di depan kelas.

\section{METODE PENELITIAN}

Jenis penelitian ini adalah penelitian Quasy Experiment (eksperimen semu). Desain penelitian yang digunakan adalah posttest only yaitu perolehan nilai kemampuan mahasiswa dalam menulis artikel ilmiah yang diperoleh di akhir pembelajaran. Subjek penelitian yaitu mahasiswa pada dua kelas di Program Studi Pendidikan Geografi FIP Universitas Kanjuruhan Malang semester ganjil 2016/2017 pada mata kuliah Geografi Sumber Daya Alam materi manajemen pengelolaan sumber daya alam. Kelas A sebagai kelas eksperimen dengan jumlah mahasiswanya 33 dan kelas B sebagai kelas kontrol dengan jumlah mahasiswanya 33. Instrumen yang digunakan yaitu rubrik penilaian. Rubrik penilaian digunakan untuk menilai kemampuan mahasiswa dalam menulis artikel ilmiah. Rubrik penilaian berisikan indikator penulisan artikel. Tiga aspek yang dinilai, yaitu: 1) Sistematika; 2) Isi/substansi; 3) Teknik penulisan. Sistematika dinilai dari urutan dan kelengkapan. Isi/substansi dinilai dari ketepatan dan kesesuaian antara judul, latar belakang, tujuan, metode penelitian, hasil dan pembahasan. Teknik penulisan dinilai dari kesesuaian penggunaan tanda baca, kalimat, dan paragraf. Data hasil penilaian artikel ilmiah mahasiswa kemudian dianalisis menggunakan $t$-test dengan taraf signifikan 5\%. Proses analisis data dilakukan melalui bantuan program SPSS 20.0 for Windows.

\section{HASIL DAN PEMBAHASAN}

Berikut ini distribusi frekuensi nilai kemampuan menulis artikel ilmiah mahasiswa kelas eksperimen.

Tabel 1. Distribusi Nilai Kemampuan Menulis Artikel Ilmiah Pada Kelas Eksperimen

\begin{tabular}{|c|c|c|c|}
\hline $\begin{array}{l}\text { Rentang } \\
\text { Nilai }\end{array}$ & Klasifikasi & $\begin{array}{c}\text { Jumlah } \\
\text { Mahasiswa }\end{array}$ & $\begin{array}{c}\text { Persentase } \\
(\%)\end{array}$ \\
\hline $91-100$ & $\begin{array}{l}\text { Sangat } \\
\text { baik }\end{array}$ & 7 & 21,21 \\
\hline $75-90$ & Baik & 19 & 57,58 \\
\hline $60-74$ & Cukup & 7 & 21,21 \\
\hline $40-59$ & Kurang & 0 & 0 \\
\hline$<40$ & $\begin{array}{l}\text { Sangat } \\
\text { kurang }\end{array}$ & 0 & 0 \\
\hline Jumlah & & 33 & 100 \\
\hline \multicolumn{4}{|c|}{$\begin{array}{c}\text { Mean: } 83,33 \\
\text { Nilai maks: } 95 \\
\text { Nilai min: } 60\end{array}$} \\
\hline
\end{tabular}

Sumber: Hasil Penelitian 
Berikut ini distribusi frekuensi nilai kemampuan menulis artikel ilmiah mahasiswa kelas kontrol.

Tabel 2. Distribusi Nilai Kemampuan Menulis Artikel Ilmiah Pada Kelas Kontrol

\begin{tabular}{|c|c|c|c|}
\hline $\begin{array}{l}\text { Rentang } \\
\text { Nilai }\end{array}$ & Klasifikasi & $\begin{array}{c}\text { Jumlah } \\
\text { Mahasiswa }\end{array}$ & $\begin{array}{c}\text { Persentase } \\
(\%)\end{array}$ \\
\hline $91-100$ & $\begin{array}{l}\text { Sangat } \\
\text { baik }\end{array}$ & 0 & 0 \\
\hline $75-90$ & Baik & 23 & 69,70 \\
\hline $60-74$ & Cukup & 5 & 15,15 \\
\hline $40-59$ & Kurang & 5 & 15,15 \\
\hline$<40$ & $\begin{array}{l}\text { Sangat } \\
\text { kurang }\end{array}$ & 0 & 0 \\
\hline Jumlah & & 33 & 100 \\
\hline \multicolumn{4}{|c|}{$\begin{array}{c}\text { Mean: } 72,27 \\
\text { Nilai maks: } 90 \\
\text { Nilai min: } 40\end{array}$} \\
\hline
\end{tabular}

\section{Sumber: Hasil Penelitian}

Perolehan nilai kemampuan menulis artikel ilmiah kelas eksperimen dan kontrol juga digambarkan dalam diagram batang berikut.

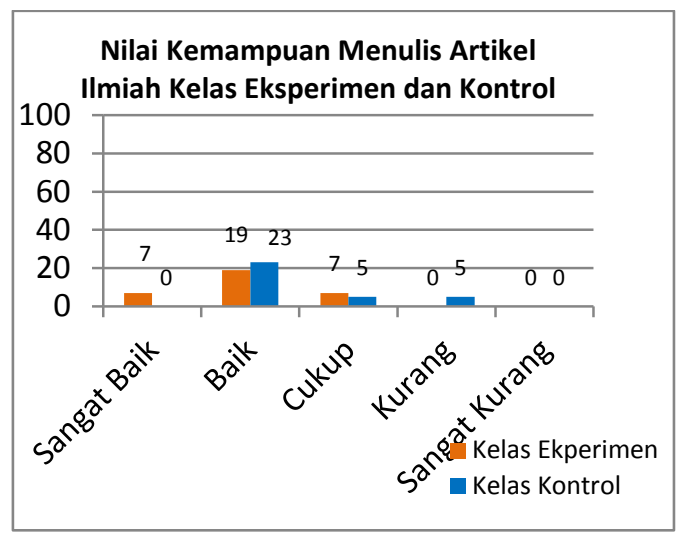

Gambar 1. Diagram Batang Nilai Kemampuan Menulis Artikel Ilmiah Kelas Eksperimen dan Kontrol

Gambar 1 di atas, menjelaskan bahwa perolehan nilai yang berbeda antara mahasiswa dengan model pembelajaran Group Investigation dan mahasiswa dengan pembelajaran konvensional (ceramah). Selanjutnya, perolehan nilai kedua kelas dianalisis menggunakan uji-t untuk menguji hipotesis penelitian. Selanjutnya berdasarkan hasil analisis $\mathrm{H}_{0}$ menunjukkan nilai sig.2tailed $=0,000$ atau $<0,05$. Jadi, $\mathrm{H}_{0}$ ditolak dan $\mathrm{H}_{1}$ diterima atau model pembelajaran Group Investigation berpengaruh terhadap kemampuan mahasiswa menulis artikel ilmiah. Ratarata nilai kelas eksperimen yakni 83,33 sedangkan kelas kontrol 72,27. Selisih rata-rata antara kelas eksperimen dan kontrol yakni 11,06.

Hasil analisis data menunjukkan bahwa model pembelajaran Group Investigation berpengaruh signifikan terhadap kemampuan menulis artikel ilmiah yaitu pada mahasiswa Pendidikan Geografi yang menempuh matakuliah Geografi Sumber Daya Alam. Hasil penelitian ini menguatkan penelitian sebelumnya, yaitu Ayu (2012) menyimpulkan bahwa model pembelajaran Group Investigation berpengaruh signifikan terhadap hasil belajar kognitif, hasil belajar afektif, dan keterampilan menulis ilmiah mahasiswa IPA Universitas Wiraraja Sumenep Madura. Mahasiswa IPA yang diperlakukan dengan model pembelajaran Group Investigation menunjukkan peningkatan hasil belajar kognitif sebesar 29\% dibandingkan kelas kontrol, hasil belajar afektif menunjukkan peningkatan $24 \%$ dibandingkan kelas kontrol, dan keterampilan menulis karya ilmiah sebesar $60 \%$ dibandingkan kelas kontrol.

Rata-rata nilai artikel ilmiah kelas eksperimen lebih tinggi dibanding kelas kontrol, meskipun dengan materi perkuliahan yang sama yakni manajemen sumber daya alam. Hal ini disebabkan tiga alasan. Pertama, mahasiswa mengalami langsung pembelajaran di luar kelas. Mahasiswa 
yang mempelajari materi sumber daya alam lebih efektif jika mengetahui dan mengalami langsung pembelajaran di luar kelas dengan melakukan investigasi. Pembelajaran ini sesuai dengan Fatchan (2009) yang menyatakan bahwa "mahasiswa akan belajar dengan sangat baik apabila mereka belajar dengan aktif, menggunakan pendekatan holistik, mengalami langsung, terpadu dan praktis dengan bimbingan dosen".

Kedua, dengan Group Investigation mahasiswa dilatih untuk melakukan penyelidikan dengan menemukan data dan fakta di lapangan yang sebenarnya tentang pengelolaan sumber daya alam di kawasan hutan Raden Suryo Kota Batu. Mahasiswa mencari fakta dan kebenaran di lapangan tentang implementasi pengelolaan hutan mulai dari pengelolaan sumber daya air, hutan, hewan dan tumbuhan, pemanfaatan limbah ternak, hingga pengelolaan sumber daya alam kaitannya dengan pariwisata. Penyelidikan di lapangan memberikan pengaruh positif terhadap kualitas artikel ilmiah mahasiswa karena data dan fakta yang dituliskan sesuai hasil sebenarnya.

Ketiga, pembelajaran pada kelas eksperimen dengan Group Investigation memberikan pengaruh yang positif pada kemampuan mahasiswa menulis artikel ilmiah karena identik dengan kerjasama antar mahasiswa. Selaras dengan pernyataan Sumarmi (2012),"Group Investigation adalah penyelidikan yang dilakukan secara berkelompok, yakni mahasiswa secara berkelompok melakukan penyelidikan dengan aktif sehingga memungkinkan menemukan prinsip". Pernyataan ini mendukung temuan pada penelitian ini yaitu adanya kerjasama kelompok dari setiap tahap Group Investigation.

Mulai dari tahap pengelompokan, perencanaan, penyelidikan di lapangan, pengorganisasian, presentasi, dan evaluasi artikel ilmiah. Kesepakatan pada perencanaan pembelajaran, penyelidikan di lapangan akan lebih mudah dilakukan. Pelaporan hasil penyelidikan berupa artikel ilmiah lebih baik karena ada proses kerja kelompok dan mahasiswa bisa bertukar pikiran untuk memperbaiki kesalahan pada artikel yang dituliskan.

Berdasarkan keenam langkah pembelajaran dengan model Group Investigation memberikan hasil pembelajaran yang positif yaitu perolehan nilai kemampuan menulis artikel ilmiah. Kelas dengan perlakuan Group Investigation mengalami langsung pembelajaran di luar kelas. Mahasiswa menyelidiki fakta, data, dan menemukan permasalahan di lapangan berdasarkan materi perkuliahan di dalam kelas yaitu manajemen pengelolaan SDA. Dengan pembelajaran Group Investigation mahasiswa diwajibkan menulis laporan hasil penyelidikan dalam bentuk artikel ilmiah. Penulisan artikel disesuaikan dengan template yang sudah disediakan dosen sebagai acuan penulisan artikel yang baik dan benar.

Pembelajaran dengan model Group Investigation memberikan hasil yang lebih tinggi dibanding dengan pembelajaran konvensional yang hanya ceramah karena pembelajaran berlangsung hanya satu arah. Aktivitas mahasiswa kelas kontrol lebih rendah karena hanya menerima materi pembelajaran tanpa mengalami langsung pembelajaran di luar kelas. Pembelajaran yang hanya memberikan kesempatan mahasiswa untuk 
mendengarkan ceramah dosen terkait dengan materi pembelajaran dinilai tidak memberikan pengaruh yang lebih tinggi terhadap kemampuan mahasiswa dalam menulis artikel ilmiah. Hal ini dikarenakan penulisan artikel akan lebih bermakna dan berkualitas jika mahasiswa mengetahui dan menyelidiki langsung ke lapangan.

Mahasiswa pada kelas kontrol tidak menuliskan data dan fakta dari hasil penyelidikan langsung ke lapangan. Hal ini menjadikan kualitas artikel yang dituliskan tidak lebih baik dari kelas eksperimen. Penulisan artikel ilmiah pada kelas kontrol lebih banyak bersumber dari hasil browsing dari internet. Topik yang dibahas pada artikel bukan kesepakatan dari diskusi dengan mahasiswa melainkan ditentukan oleh dosen dan kelompok juga dibentuk oleh dosen. Kegiatan pada kelas kontrol tidak memberikan ruang pada mahasiswa berinteraksi langsung dengan kenyataan di lapangan. Padahal, materi yang diberikan adalah materi sumber daya alam yang kontekstual.

\section{KESIMPULAN}

Berdasarkan penelitian yang dilakukan, maka kesimpulannya yaitu model pembelajaran Group Investigation berpengaruh terhadap kemampuan menulis artikel ilmiah pada mahasiswa Pendidikan Geografi Univeristas Kanjuruhan Malang.

\section{DAFTAR RUJUKUAN}

Arrends, R.I. 2008. Learning to Teach. Sixth Edition. New York: McGraw-Hill.

$\begin{array}{ccc}\text { Ayu. 2012. Pengaruh } & \text { Model } \\ \text { Pembelajaran } & \text { Group } \\ \text { Investigation Terhadap } & \text { Hasil }\end{array}$

Belajar Kognitif, Hasil Belajar Afektif, dan Keterampilan Kerja Ilmiah Mahasiswa IPA Universitas Wiraraja Sumenep Madura. Tesis tidak dipublikasikan. Malang: Program Pascasarjana.

Dewey, J. 1970. Experience and Education. New York: Collier.

Fatchan, Ach dkk. 2009. Pengembangan dan Penerapan Pembelajaran Kontekstual Berbasi Pemecahan Masalah di Sekolah Daerah Rawan Bencana Pada Pembelajaran Materi IPS-Geografi di SLTP. Malang: DP2M, Lemlit UM.

Joice, B \& Weil Marsha. 1996. Models of Teaching. Prentice-Hall Inc. New Jersey.

Kardi, Soeparman dan Mohammad Nur. 2009. Pengajaran Langsung. Surabaya: Universitas Negeri Surabaya.

Peacock, Alan. 2006. The Lasting Impact of School Trips._: Honorary Research Fellow, The Innovation Centre, University of Exeter.

Sumarmi. 2012. Model-model Pembelajaran Geografi. Malang: Aditya Media Publishing.

Suprijono, Agus. 2009. Cooperatif Learning Teori \& Aplikasi Paikem. Yogyakarta: Pustaka Belajar. 